\title{
Sino-Western Regional Differences and Translation
}

\author{
ZHAO You-bin \\ Jinan University, Zhuhai City, China

\begin{abstract}
Culture difference always exists in many aspects. Due to the national characters, regionalism, and times, translation can not be in a position when we try to translate without considering the language culture. Cultural difference between English and Chinese, determines the different features between English and Chinese.
\end{abstract} \\ Keywords: Sino-Western cultures, regional culture, translation
}

\section{Introduction}

We all know that language is a part of culture and plays a very important role in culture. Some social scientists consider language as the keystone of culture. They maintain that culture would not be possible without language. On the other hand, language is influenced and shaped by culture; it also reflects culture. In general terms, language is the symbolic presentation of people's character, which contains their cultural and historical backgrounds as well as their ways of living and thinking and their life values. So we need to pay great attention to Chinese and Western cultural differences, especially Sino-Western regional differences when we try to translate. Due to the differences between Chinese and Western culture, only through finding the correct strategies to the culture factors, can we improve the accuracy of the translation.

According to the definition put forth by Nida, cultural differences refer to the differences between historical heritage, social customs and cultural tradition between different countries and religions, which are the reflection of the history developing. From the above explanation, we may have an understanding about the culture on the whole. Cultural differences are broad and it involves many aspects, so it is very difficult to give an accurate definition. Generally speaking, we can consider that, cultural differences refer to the different cultural values, different thought pattern, different social norms, and different communication styles among different people from different countries and cultural backgrounds.

\section{Regional Differences}

Regional culture refers to the culture formed by geographical, natural conditions, and environmental culture. Living in different natural environment, people will form different cultures and every culture has different characteristics because of its different geographical characteristics, climate, and environment. Britain is an island and eating fish reminds them of their practical and spiritual dependence on the sea. Britain has long and winding coastline. Shipping and fishing industry, therefore, have a huge influence on formation and development of English language. Although China has a long coast, China is an agricultural country since ancient times. So the

ZHAO You-bin, Professor, Dean of School of Translation Studies, Jinan University. 
development of Chinese language associated with agriculture for a long time.

Language cannot be separated from people's living environment, and the situation that different environment lead to language diversity can be seen everywhere. Endowed with terra firma grandeur, China is a mountainous country, while Britain is a typical island. The situations are reflected in the words of both Chinese and English. Regional cultural differences on translation of Chinese and western have a great influence and the examples are discussed as follows.

\section{Characteristics of Sino-Western Regions}

Chinese's temperature is different from Britain's due to the difference of geographical position between China and Britain. China is located in the Eastern Hemisphere, the east Pacific. The east wind from the Pacific warms all over the vast land when the spring coming. The east wind is often associated with spring in China. Tang Dezong made the poem: “东风变梅柳, 万汇生春光”. The poem wrote by Xin Qi-ji: “东风夜放花千树, 更吹落, 星如雨”. The east wind is warm in the eyes of the Chinese people. Chinese people, therefore, much praise the east wind, comparing it to the spring breeze. Spring returns to the earth after the east wind blowing across the land. Everything begins to grow in this time. It is a symbol of vigorous and progress. Here are the pomes to prove: “东风夜放千树, 更吹落星如雨” (the east wind will put thousands of trees at night, and blow the star like rain). “东风破早梅, 向暖一枝开。冰雪无人见, 春从天上来。” “春城无处不飞花, 寒食东风 御柳斜。” “To borrow the east wind” refers to the success depend on all favorable conditions. The metaphor "The east wind prevails over the west wind" refers to progressive and revolutionary forces overwhelm the backward, reactionary forces. The old saying "Everything is ready, only a strong wind” means that "East Wind" is a timely thing. “Dongfeng songs” made by Guo Moruo has the poem: “东风吹遍人间后, 紫红万千满地开”. The east wind implies here the vitality of spring wind.

What is image of the east wind in the eyes of westerns? The western winds blow over Britain all the year. They blow from the south west. In fact, the UK's latitude is similar to the Northeast of China, but Britain being an island has maritime climate which is much milder in winter. The east wind of Britain comes from the North of continental Europe. English describe the east wind like: a keen east wind; biting east winds; a piercing east wind; How many winter days have I seen him, standing bluenosed in the snow and east wind!

Therefore, the east wind is a biting wind in the eyes of English. What about the west wind? For English people, west winds are warm wind, they sent the spring to Britain. These warm western winds also carry moisture from the ocean. So there are many English poems praising westerly winds. Shelley's "Ode to the West Wind” is a familiar example. Britain's warm wind - the west wind is the cold wind in China. There are some poems describing the west wind in ancient times. For instance, “飒飒西风满院裁, 荵寒香冷蝶难来”, “昨夜西风过园 林, 残菊飘零满地金”. By this token, the differences between the east wind and the west wind are obvious. So how to choose the translation methods, especially in poetry translation, is very important for translators. In my opinion, literal translation is surely a good way to translate. The communication between the east and the west has thousands of years in history. What's more, the communication between Chinese and English has already in a deeper degree. People who have knowledge can recognize the literal translation for dongfeng and xifeng.

Describing a person who is extravagance and waste,“挥金如土”- as Chinese idiom, we translate the idiom into English is “spend money like water”. In Chinese, we usually use the word such as “土” and “山”, while in 
English we usually use associative meaning words such as "water" and "sail”. "Like water" means abundant and this phrase made it clear that different geographical environment between the two countries can lead to language differences.

China's geographical environment forms the feature that China is abundant in bamboo. The idiom using bamboo as a metaphor in Chinese speech is not rare. The British does not have the condition to grow bamboo, so we don't use the bamboo to make metaphor in English. In china, the idiom "bamboo shoots after a spring rain” is often used to describe rapid and a lot of things or the things are springing up everywhere. While English's saying is "the like a mushroom after rain". Again, Chinese is used to describe someone knows what to do in his mind before doing things with the idiom “胸有成竹”. While English use “to have a card up one sleeve” to express the meaning.

As we know that English is an island country. The seafaring and shipping industry are well-developed in Britain for a long time, which have a significant impact on the English language. We can illustrate this point only to find that people in Britain like to use fish to compared persons, such as bigfish (a tycoon), coolfish (a cheek guy), cullfish (a wet blanket), freshfish (a new prisoner or young prisoners), loosefish (the slutty people), oldfish (the freak guy), poorfish facile (someone who is easily deceived and stupid), and shyfish (a shy person). To deal with the cultural differences in intercultural translation, various skills can be adopted, including direct translation, modeling application, free translation and so on. We can use modeling application and free translation in this situation.

Regional cultural differences make different understanding of the same things existed for different ethnic groups. Some things have rich connotation and denotation in a language culture. They can cause good association, while in another language culture they are fairly unimpressive. Farmers in straw hats plough the land with cows since ancient times in China. The farm cattle and farmers are closely associated and both of them are hardworking and honest. So the Chinese have the deep feelings to the cow. In Chinese traditional culture, the cattle is the symbol of diligence. People often compare those who work diligently and conscientiously or willingly bear the burden of hard works hardworking to the willing ox. Generally, Chinese ancients used cattle and water buffalos rather than horses to cultivate. Unlike China, the use of horses for ploughing prevails in Britain in ancient time. Therefore the horse is the symbol of bearing hardships and standing hard work in the British and American culture. In Chinese there is "as strong as cow”. If you want to translate it into English, it is "as strong as a horse”, and cannot be translated into “as strong as a cattle”. The Chinese saying such as“吹牛”, “做老黄牛”, and “牛不 喝水强按头” should be respectively translated to “talk horse”, “work like a horse”, and “You may take a horse to the water, but you can’t make him drink”. We all know the phrase “howling at the moon” (对牛弹琴) is not a commendatory term, but some British farmers do not think so. Most of British farmers enjoy their pastoral life and they treat their animals as friends.

When translating this kind of idiom or words, we should avoid the literal translation and apply the method which is replacing the original metaphors according to their respective national culture characteristics. And that is the way to translate and make the sentence's meaning tread different paths that lead to the same destination.

\section{Conclusion}

To sum up, translation is the conversion between different languages. Transformation is conducted in the 
contrast of language. To overcome the differences between English and Chinese in translation process, we must not only be familiar with two kinds of different forms of language, but also understand the barriers consisted of the cultural differences in the different languages, including the regional differences. As a translator once put, both the difficulty and easiness of translation, or both the good and bad, are mainly related to culture rather than the language. Only through the further understanding to the culture and language, systematic and specific contrast, can we understand and correctly deal with cultural differences in different national languages. Each national language expresses the thought content, feeling and style faithfully and shows it accurately. So Wang Zuoliang once said, the translator must be a real culture worker.

Translation is the language communication. And what is important is that translation is the communication of culture. Therefore, in the process of translation, the translator is not only to understand and analysis of the source language, but also analysis of the deep differences in cultural concept of the target language. Meeting the above requirements we could guarantee the information in the translation's source language to get real. This needs we are sensitive to cultural differences between languages in the translation work.

\section{References}

Carroll, J. B. (1973). Linguistic relativity and language learning (Vol. 1). Oxford: Allen and Corder.

McCarthy, D. (2001). Words \& idioms in Amican English. Shanghai: Changchun \& Shanghai Haiwen Audio and Visual Press.

GUI, T. F. (1999). A Chinese-English dictionary of idiom (with Chinese explanations). Hangzhou: Zhejiang Art Press.

GUO, S. L., \& YU, F. M. (1999). A comparative study of English and Chinese idioms. Shanghai: Shanghai Jiaotong University Press.

LI, S. T. (1999). Chinese idioms and their stories. Shanghai: China International Radio Press.

Nida. E. A. (1993). Language, culture and translating. Shanghai: Shanghai Foreign Language Press. 